\title{
Inoculation- and Nitrate-Induced CLE Peptides of Soybean Control NARK-Dependent Nodule Formation
}

\author{
Dugald E. Reid, Brett J. Ferguson, and Peter M. Gresshoff \\ Australian Research Council Centre of Excellence for Integrative Legume Research, John Hines Building, The University \\ of Queensland, St. Lucia, Brisbane, Queensland 4072, Australia
}

Submitted 15 September 2010. Accepted 29 December 2010.

Systemic autoregulation of nodulation in legumes involves a root-derived signal $(Q)$ that is perceived by a CLAVATA1like leucine-rich repeat receptor kinase (e.g. GmNARK). Perception of $Q$ triggers the production of a shoot-derived inhibitor that prevents further nodule development. We have identified three candidate CLE peptide-encoding genes (GmRIC1, GmRIC2, and GmNIC1) in soybean (Glycine max) that respond to Bradyrhizobium japonicum inoculation or nitrate treatment. Ectopic overexpression of all three CLE peptide genes in transgenic roots inhibited nodulation in a GmNARK-dependent manner. The peptides share a high degree of amino acid similarity in a 12-amino-acid C-terminal domain, deemed to represent the functional ligand of GmNARK. GmRIC1 was expressed early (12 h) in response to Bradyrhizobium-sp.-produced nodulation factor while $G m R I C 2$ was induced later $(48$ to 72 h) but was more persistent during later nodule development. Neither GmRIC1 nor GmRIC2 were induced by nitrate. In contrast, GmNIC1 was strongly induced by nitrate $(2 \mathrm{mM})$ treatment but not by Bradyrhizobium sp. inoculation and, unlike the other two GmCLE peptides, functioned locally to inhibit nodulation. Grafting demonstrated a requirement for root GmNARK activity for nitrate regulation of nodulation whereas Bradyrhizobium sp.-induced regulation was contingent on GmNARK function in the shoot.

Most legume species form a symbiotic relationship with nitrogen-fixing soil bacteria collectively called rhizobia. This occurs via a complex signaling exchange between the plant and bacteria and results in the formation of specialized root organs known as nodules (Ferguson et al. 2010). Within the nodule, the plant receives fixed atmospheric nitrogen from the bacteria in exchange for photoassimilates (Udvardi et al. 1988). Symbiotic nitrogen fixation is critical to legume cultivation because it provides both economic and environmental advantages over other crops. Additionally, nodule formation provides an excellent system to study lateral organ development, short- and long-distance signaling, and developmental regulation within plants.

Nodulation commences following the plant's perception of specialized lipooligosaccharide signal molecules produced by the bacteria called nodulation (Nod) factors (NF) (Ferguson and Mathesius 2003; Kouchi et al. 2010). Soybean (Glycine

Corresponding author; P. Gresshoff; Telephone: +617-33653550; Fax: +617-33653556; E-mail: p.gresshoff@uq.edu.au

* The $\boldsymbol{e}$-Xtra logo stands for "electronic extra" and indicates that two supplementary tables and a supplementary figure are published online. max) is the most widely cultivated legume (Ferguson and Gresshoff 2009) and forms determinate type nodules in a symbiosis with Bradyrhizobium japonicum and Rhizobium fredii. In soybean, NF are perceived by LysM-type receptor kinase receptors, namely GmNFR5 (Indrasumunar et al. 2010a) and GmNFR1 (Indrasumunar et al. 2010b). Downstream signaling events in the root lead to the reinitiation of cortical cell divisions, pericycle cell divisions, and vascularization and the initiation of a lateral nodule meristem.

Early signaling events have been well-studied in model legume species, including Lotus japonicus, Medicago truncatula, Pisum sativum, and G. max. This has allowed for the identification of key components required for nodule development (Ferguson et al. 2010; Oldroyd and Downie 2008). Initial signaling events lead to calcium spiking in and surrounding the nucleus and trigger the activation of CCamK (Kosuta et al. 2008; Oldroyd and Downie 2006) which, together with the activation of a cytokinin receptor (Gonzalez-Rizzo et al. 2006; Murray et al. 2007; Tirichine et al. 2007), results in the modulation of the expression of several early nodulation genes (Heckmann et al. 2006; Schauser et al. 1999; Vernie et al. 2008).

The plant regulates the number of nodules it forms to optimize its response to both internal and external stimuli, including preexisting infection events and environmentally available nitrogen. The inbuilt mechanism is called autoregulation of nodulation (AON) (Caetano-Anollés and Gresshoff 1991a and b). This mechanism is responsible for legumes exhibiting a distinct crown nodulation phenotype. The zone affected is the region of the root that has emerging root hairs that are susceptible to rhizobia infection and cell division initiation (Bhuvaneswari et al. 1980, 1981; Calvert et al. 1984). In soybean, this zone is sliding because AON continually permits infection and early cell division but blocks the advance toward nodule meristem formation (Calvert et al. 1984; Mathews et al. 1989). Mutants in AON remove this secondary blockage, allowing nodule formation over a larger root portion, which leads to more nodules being formed and an increased "nodulation interval" spanning the root system (Carroll et al. 1985a and b). It is of interest that, in both $P$. sativum and $M$. sativa, nodulation is blocked at an earlier stage, because the arrested nodule foci observed in soybean are not observed in these species (Caetano-Anollés and Gresshoff 1991a and b; Sagan and Gresshoff 1996).

The current model for AON (Caetano-Anollés and Gresshoff 1991a and b; Ferguson et al. 2010; Gresshoff and Delves 1986; Magori and Kawaguchi 2009) begins with the production of a root-derived cue $(\mathrm{Q})$ that is produced following both the first nodulation-induced cell divisions in the root (Caetano-Anollés and Gresshoff 1990; Li et al. 2009) and further nodule maturation and functioning associated with the onset of nitrogen fixa- 
tion (Li et al. 2009) (Fig. 1). Q is subsequently transported to the shoot, presumably via the xylem stream, where it is perceived by a phloem parenchyma-localized leucine-rich repeat (LRR) receptor kinase (Nontachaiyapoom et al. 2007). This LRR receptor kinase is similar in gene and protein structure to CLAVATA 1 of Arabidopsis, and is encoded by GmNARK in soybean (Searle et al. 2003) and its orthologs in other legumes: LjHARl (Krusell et al. 2002; Nishimura et al. 2002a), PsSYM29 (Krusell et al. 2002), GsNARK (G. soja) (Searle et al. 2003) and MtSUNN (Schnabel et al. 2005). Loss-of-function mutations in these orthologs lead to increased nodulation (termed "hyper-" and "supernodulation"), increased portion of the root showing nodule development (the nodulation interval), altered lateral root growth, and decreased sensitivity to nitrate inhibition of nodulation (Fig. 1). To date, GmNARK is the only genetic component that has been identified in the AON pathway of soybean (Searle et al. 2003), although related genes and nodule regulation mutants have been defined in other legumes showing altered AON: Ljklavier (Oka-Kira et al. 2005) Pssym28 (Krusell et al. 2011; Sagan and Duc 1996), MtrdnI (Frugoli 2010), Psnod3 (Postma et al. 1988) Ljtml (Magori et al. 2009), Ljrdh1 (Ishikawa et al. 2008), and LjASTRAY (Nishimura et al. 2002b). Using grafting and split-root approaches, AON and GmNARK/LjHAR1/MtSUNN were shown to act systemically in the shoot to regulate nodule numbers in the root (Delves et al. 1986, 1987; Jiang and Gresshoff 2002; Krusell et al. 2002; Nishimura et al. 2002a; Olsson et al. 1989; Penmetsa et al. 2003).

Following the perception of Q by NARK, a novel signal is produced that acts as a shoot-derived inhibitor (SDI) of nodu- lation. SDI is transported from the shoot to the roots, where it prevents further nodulation events (Mathews et al. 1989). Thus far, work to identify SDI has indicated that it is likely a small molecule (less than 1,000 Da) that is not a protein, peptide, or RNA (Lin et al. 2010).

In soybean, all AON mutants isolated have been found to have mutations in GmNARK (Nishimura et al. 2002a; Searle et al. 2003; J. Batley, unpublished data). Interestingly, all AON mutants are also nitrate tolerant, because they form nodules in the presence of nitrate levels that are otherwise inhibitory to nodulation in wild-type (WT) plants (Carroll et al. 1985a and b; Penmetsa et al. 2003; Schnabel et al. 2005; Wopereis et al. 2000). That GmNARK mutations affect both AON and nitrate regulation of nodulation indicates that this gene is a common component of both regulatory mechanisms. This would also appear to explain why GmNARK expression is observed in the phloem parenchyma of both the shoot and the root (Nontachaiyapoom et al. 2007) but, in contrast to AtCLAVATA1, not in the root or shoot apical meristem. Furthermore, recent work has shown that both local and systemic regulation of nodulation occurs in response to nitrate (Jeudy et al. 2010).

The structural similarity of GmNARK to CLAVATA1 in Arabidopsis led to the proposal (Searle et al. 2003) that the ligand of GmNARK may be a CLE peptide, similar to the CLV3 ligand that binds to CLAVATA1 (Clark et al. 1997; Fletcher et al. 1999; Kondo et al. 2006, 2008; Ogawa et al. 2008). CLE peptides are required for several plant developmental and regulatory processes, including for the regulation of the shoot (Fletcher et al. 1999) and root (Fiers et al. 2004) apical meristems and for vasculature differentiation (Hirakawa

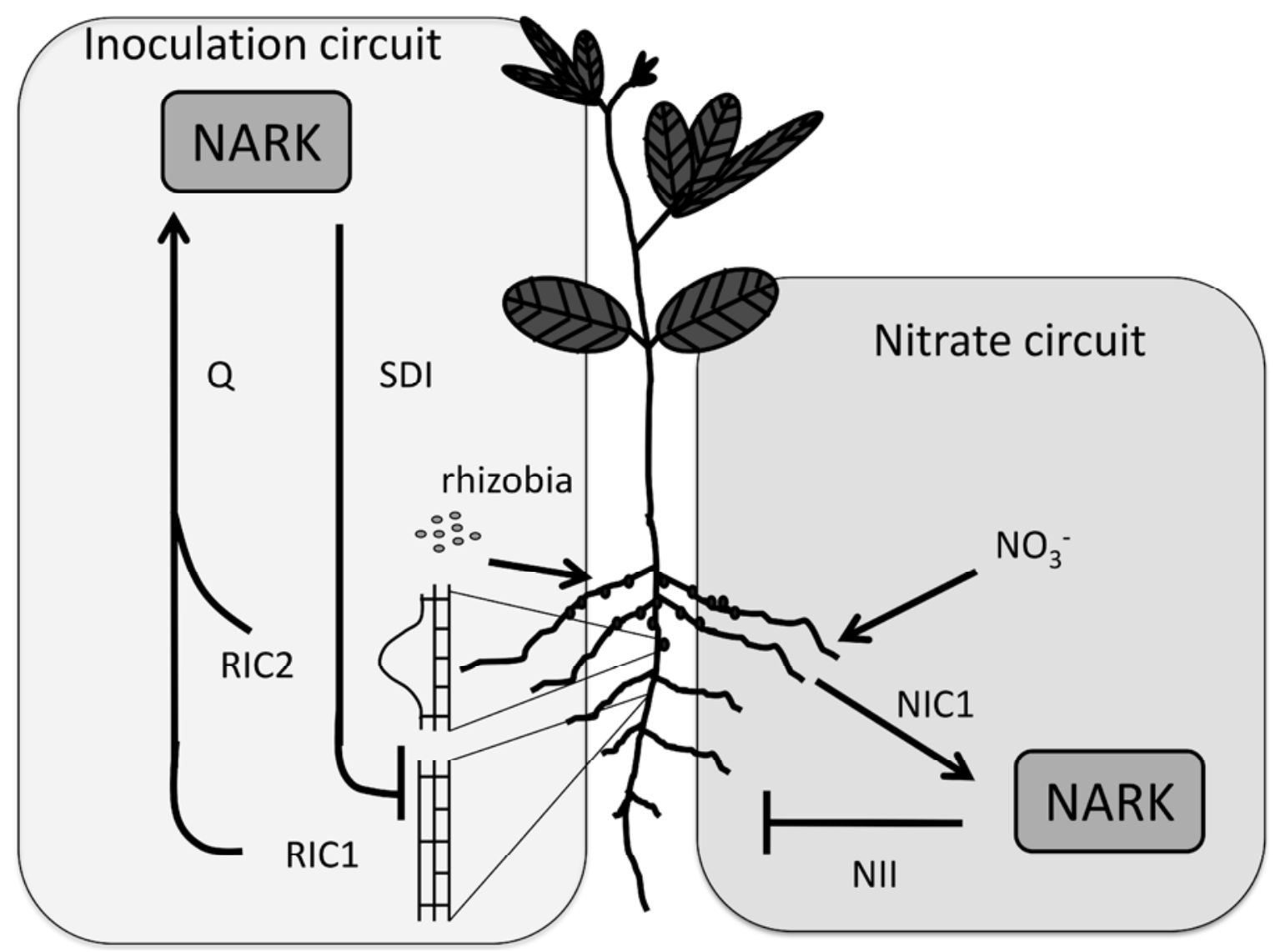

Fig. 1. Proposed model of NARK-dependent CLE activity in the root and shoot. Autoregulation of nodulation involves long-distance signaling requiring the interaction of RIC1 or RIC2 with NARK in the leaf and the subsequent inhibition of nodulation via the production of a shoot-derived inhibitor (SDI). Local nitrate inhibition of nodulation is established by the interaction of NIC1 with NARK in the root leading to production of an SDI-like nitrate induced inhibitor (NII) of nodulation. 
et al. 2010; Ito et al. 2006). CLE peptides are characterized by an N-terminal signal peptide and a C-terminal region of approximately 12 to 13 amino acids that is proposed to act as the final active product (Oelkers et al. 2008).

Significant modification of CLE peptides occurs post-translationally, including proteolytic cleavage (Ni and Clark 2006; $\mathrm{Ni}$ et al. 2010), hydroxylation at key prolines (Kondo et al. 2006; Ohyama et al. 2009), and glycosylation (arabinose addition at proline 7) (Ohyama et al. 2009; Shinohara and Matsubayashi 2010). There is some debate in the literature but the best evidence indicates that CLV3 functions as a 12- or 13amino-acid triple- $\beta$-1,2-linked arabinosylated peptide (Kondo et al. 2006; Ohyama et al. 2009).

To date, CLE peptides have been identified that are induced specifically by rhizobia or by either rhizobia or nitrate. All reduce nodulation in $L$. japonicus and $M$. truncatula when ectopically overexpressed in transgenic roots. Whereas the $L$. japonicus peptides only reduced nodulation effectively in WT plants (Okamoto et al. 2009), the M. truncatula peptides also exhibited partial inhibition in hypernodulating Mtsunn-1 plants (Mortier et al. 2010). However, a complete lack of nodule suppression which was not seen in the Mtsunn-1 background was observed when MtCLE12 was overexpressed using another allele of Mtsunn (Mtsunn-4) (I. Saur, N. Imin, and M. Djordjevic, personal communication). Furthermore, the large number of LRR receptor-like proteins (Diévart and Clark 2004) and CLE peptide ligands (Oelkers et al. 2008) suggests that additional CLE peptides and LRR receptor partners may regulate plant development.

We investigated the function of CLE peptides in the regulation of soybean nodulation, and identified three CLE peptide genes that exhibited either Bradyrhizobium Nod factor- or nitrate-induced gene expression. We designated these genes as rhizobia-induced CLE (RICl and RIC2) and nitrate-induced CLE (NICl). We show that overexpression of the inoculationdependent CLE genes (RIC1 and RIC2) inhibited soybean nodulation in both a systemic and NARK-dependent manner. In contrast, overexpression of the nitrate-responsive CLE (NICl) only partially reduced nodulation, and appeared to function in a local yet still NARK-dependent manner. Grafting experiments using WT and nark mutant plants grown under several nitrate conditions confirmed this local role for NARK in nitrate regulation of nodulation. We also showed differences in the localization of the nodule inhibition responses induced by inoculation- or nitrate-responsive CLE peptides. We propose that these differences may account for the different yet overlapping roles of nitrate- and inoculation-dependent regulation of nodulation in soybean.

\section{RESULTS}

\section{Identification of Bradyrhizobium inoculation- and nitrate-responsive CLE peptides.}

To identify candidates for inoculation- or nitrate-dependent CLE peptides involved in nodule regulation, searches were undertaken based on sequence homology with the LjCLE-RS1/2 protein sequences (Okamoto et al. 2009). BLAST searches identified two $M$. truncatula genes upregulated in response to inoculation in the Medicago gene atlas (Benedito et al. 2008), which have subsequently been shown to reduce nodulation when overexpressed (Mortier et al. 2010). The peptide sequence of all rhizobia inoculation-dependent legume CLE peptides was aligned using ClustalX2 to produce a consensus sequence (Larkin et al. 2007). Publicly available soybean genome sequences (Phytozome) (Schmutz et al. 2010) and expressedsequence tag sequences (National Center for Biotechnology Information $[\mathrm{NCBI}]$ ) were searched to identify soybean se- quences sharing homology with this consensus sequence or with the $L$. japonicus and $M$. truncatula CLE sequences. Searches focused on genes that shared the greatest similarity with the C-terminal CLE domain. Three soybean CLE genes were subsequently identified as candidates for either Bradyrhizobium sp. inoculation or nitrate response. These genes were designated RIC1, RIC2, and NICl (Figs. 2 and 3).

Further BLAST searches conducted in soybean identified one highly similar homolog for each of the three CLE genes likely resulting from the ancestral soybean allopolyploidization event (Fig. 2). Primers specific to each of the genes have indicated that the duplicate copies in each case are not tran-

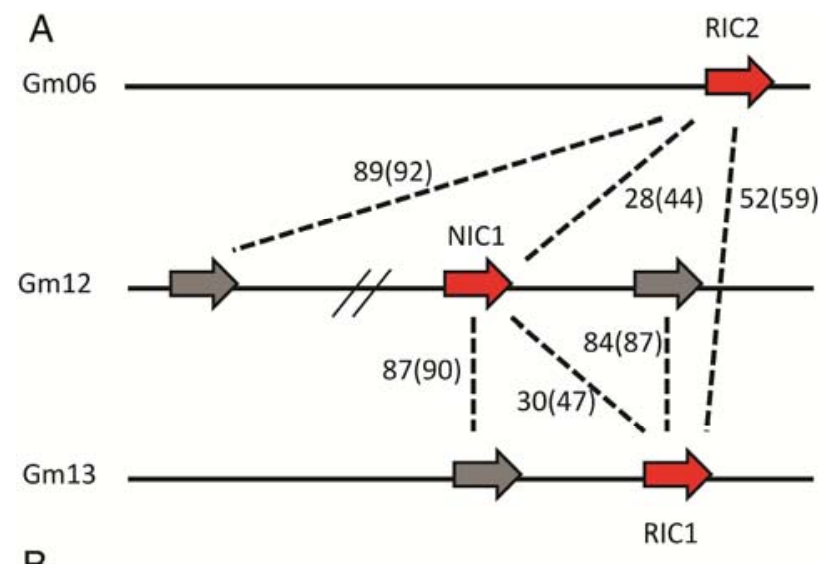

B

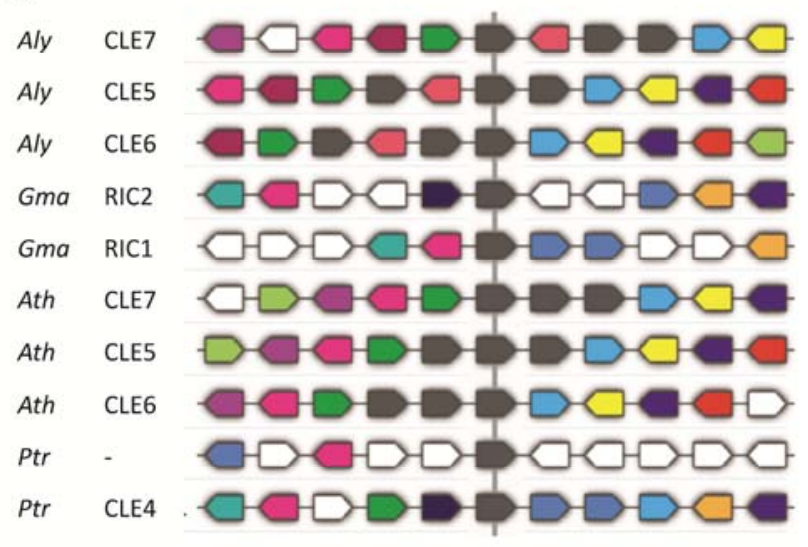

C

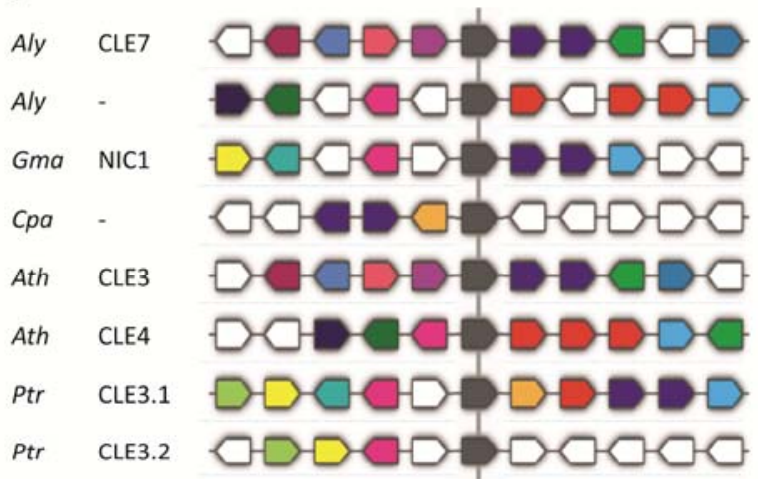

Fig. 2. Microsynteny and homology between GmCLE genes. Amino acid conservation (percent identity and percent similarity) between each of the CLE genes was highest between each gene (red) and its inactive duplicate (gray) and between the inoculation-responsive CLEs A, Phytozome cluster analysis showed a well conserved region of synteny exists between species for B, RIC1 or RIC2 and C, NIC1. Aly, Arabidopsis lyrata; Gma, Glycine max; Cpa, Carica papaya; Ath, A. thaliana; Ptr, Populus trichocarpa. 
scriptionally active in the tissue and treatment types tested in this study based on reverse-transcription quantitative polymerase chain reaction (RT-qPCR) analyses (data not shown). RICl and NICl are located in syntenous regions of chromosome 13 and 12 , respectively. In each case, the duplicate is located on the syntenous chromosome region adjacent to the actively expressed CLE (Fig. 2). RIC2 has a homolog in a syntenous region of chromosome 12 independent of this locus (Fig. 2). The degree of protein similarity or identity suggests that RIC1, RIC2, and NIC1 belong to an ancient CLE peptide gene family that diverged (by 50 to $80 \%$ ) but then duplicated as part of one of the genome-wide polyploidization events that occurred 59 and 13 million years ago (Schmutz et al. 2010). Subsequent divergence (12 to $15 \%$ ) and genome dispersion has since led to their current sequence state. Remarkably, the 12-residue C-terminal region remained conserved, suggesting functional constraints.
Sequence characteristics

of the Bradyrhizobium inoculation-induced CLE peptides.

Peptide elicitors of AON are predicted to require export from the producer cell to the xylem that is dependent on an N-terminal signal peptide. SignalP 3.0 analysis (Bendtsen et al. 2004) predicted that RIC1, RIC2, and NIC1 possess an N-terminal signal peptide which comprises approximately 30 hydrophobic amino acids, with the most likely cleavage site for the signal peptide being after 28, 29, and 26 amino acids for RIC1, RIC2, and NIC1, respectively (Fig. 3A). This analysis also showed that the signal peptide region of the inoculation-dependent CLE peptides shared areas of high conservation, including a well-conserved motif identified by Okamoto and associates (2009) (at least four of the seven legume CLE sequences were conserved at each residue) of 'FSTFFMTLQARSL' encompassing the predicted signal peptide cleavage site. NIC1 showed

A

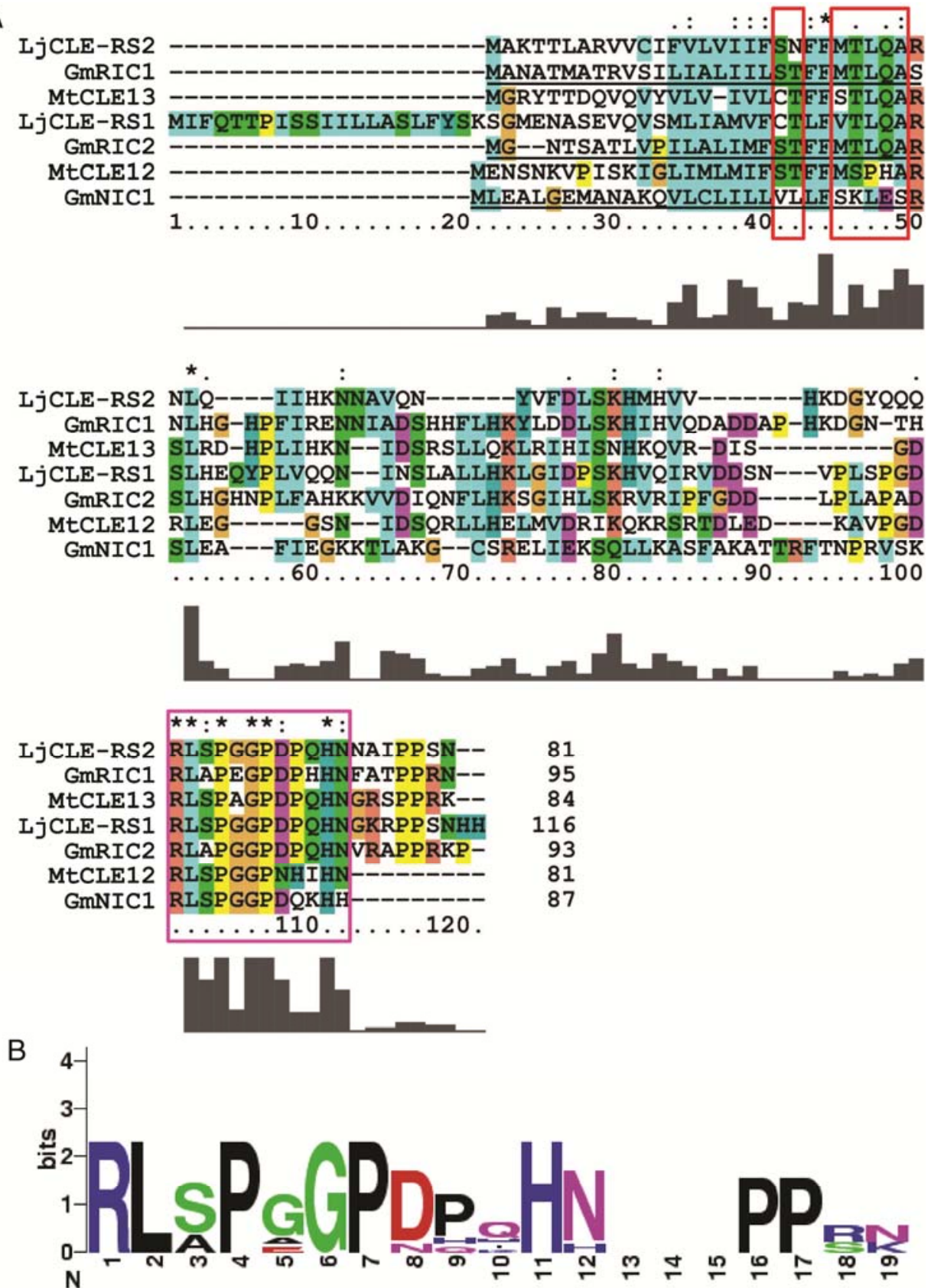

Fig. 3. Multiple sequence alignment of legume inoculation and nitrate responsive CLEs A, Predicted signal peptide of the soybean CLE peptides is underlined in black, the conserved signal peptide residues altered in NIC1 are enclosed by a red box, and the conserved 12-amino-acid CLE domain is enclosed by a pink box. B, A logo alignment (Crooks et al. 2004) of the CLE domain and C-terminal extension illustrates the degree of conservation at each residue. 
the most significant divergence from this motif because it lacks several of the nucleophilic and hydrophobic amino acids. Two well-conserved proline residues, outside of the canonical 12-amino-acid CLE peptide region (Oelkers et al. 2008), were also identified close to the $\mathrm{C}$-terminus and are conserved between L. japonicus and M. truncatula (Fig. 3A and B); their function is currently obscure.

\section{Expression pattern of $G m C L E$ genes.}

Soybean primary root tissue corresponding to the area of root-hair emergence at the time of Bradyrhizobium sp. inoculation was harvested in a time-course manner to identify genes responding to early infection events (S. Hayashi, B. Ferguson, and P. Gresshoff, unpublished data). RT-qPCR studies using this tissue showed that RICl expression was significantly upregulated in response to inoculation with effective WT Bradyrhizobium spp. relative to the ineffective nod $C^{-}$mutant (Fig. 4A), which is unable to produce Nod factor because of a chitin synthase deficiency (Debellé et al. 1992; Sanjuan et al. 1992). This difference in expression was significant as early as $12 \mathrm{~h}$ after inoculation and increased until the last tissue collection time in this study at $72 \mathrm{~h}$. It also demonstrates NF dependence for RIC1 expression. In contrast, more mature, nodulated root tissue (14 days after inoculation) showed low RICl expression (Fig. 5). NIC1 expression also responded slightly to inoculation; however, this was not detectable until $48 \mathrm{~h}$ after inoculation and was markedly weaker relative to RICl expression levels (Fig. 4A). RIC2 expression was not significantly changed until $72 \mathrm{~h}$ after inoculation (Fig. 4a) but was induced thereafter because mature, nodulated root tissue (14 days after inoculation) showed high RIC2 expression (Fig. 5).

In an initial study to determine whether nitrate can induce the expression of the soybean CLE genes, root tissue was harvested after being treated for 2 weeks with either 0 or $10 \mathrm{mM}$ $\mathrm{KNO}_{3}$. Using RT-qPCR, NICl expression was significantly induced by nitrate relative to the control, whereas $R I C l$ and RIC2 expression remained unaffected (Supplementary Fig. $\mathrm{S} 1$ ). A temporal analysis to identify the induction of NICl expression by nitrate was subsequently performed using root tissue harvested at 0,8 , or $24 \mathrm{~h}$ after the commencement of 10 $\mathrm{mM} \mathrm{KNO}{ }_{3}$ treatments. After $8 \mathrm{~h}, \mathrm{NICl}$ expression was significantly elevated and increased further by $24 \mathrm{~h}$ (Fig. 4B).

To determine whether NICl expression correlated with the inhibition of nodulation caused by nitrate, various nitrate concentrations were tested. Soybean plants were treated with either $0,2,5,10$, or $15 \mathrm{mM} \mathrm{KNO}_{3}$ for 2 days prior to and 2 weeks following B. japonicum CB1809 inoculation. The treated plants were then harvested concurrently for RT-qPCR and nodule count analyses. $\mathrm{NICl}$ was significantly induced by $\mathrm{KNO}_{3}$ at levels as low as $2 \mathrm{mM}$ and reached a plateau after the $5 \mathrm{mM}$ treatment, while nodule numbers per plant were reduced in an inverse manner (Fig. 5). In contrast to the early inoculation time course data, RICl expression did not appear to correlate with mature nodule numbers (and was significantly lower in this mature tissue), whereas RIC2 expression correlated strongly, exhibiting reduced expression levels at higher nitrate concentrations (Fig. 5).

Similar to nodulation, the systemic regulation of root arbuscular mycorrhizal infection acts through GmNARK in the shoot (Meixner et al. 2005, 2007). To determine whether any of the three soybean $C L E$ genes were upregulated by arbuscular mycorrhizal infection and, thus, had a role in their regulation, RTqPCR was performed using cDNA from Glomus intraradicesinfected soybean roots (cDNA provided by S. Schaarschmidt and B. Hause, Halle, Germany). No significant change in the expression of the CLE genes relative to that detected in uninfected plants was observed at 5, 14, or 70 days after infection with $G$. intraradices in either WT Bragg or nts1116 hypernodulating mutant plants.

\section{Cloning and transgenic expression of $G m C L E$ genes.}

To determine whether the soybean CLE peptides regulate nodulation in a NARK-dependent manner, a reverse-genetics approach employing ectopic overexpression in a chimeric hairy-root system was used. Overexpression of the systemic Q signal would be expected to inhibit nodulation, even in nontransformed roots. To test this, the complete coding sequences (CDS) of RIC1, RIC2, or NIC1 were cloned into the pKANNIBAL vector for the expression of efficient RNAi constructs (Wesley et al. 2001). However, to generate overexpressing
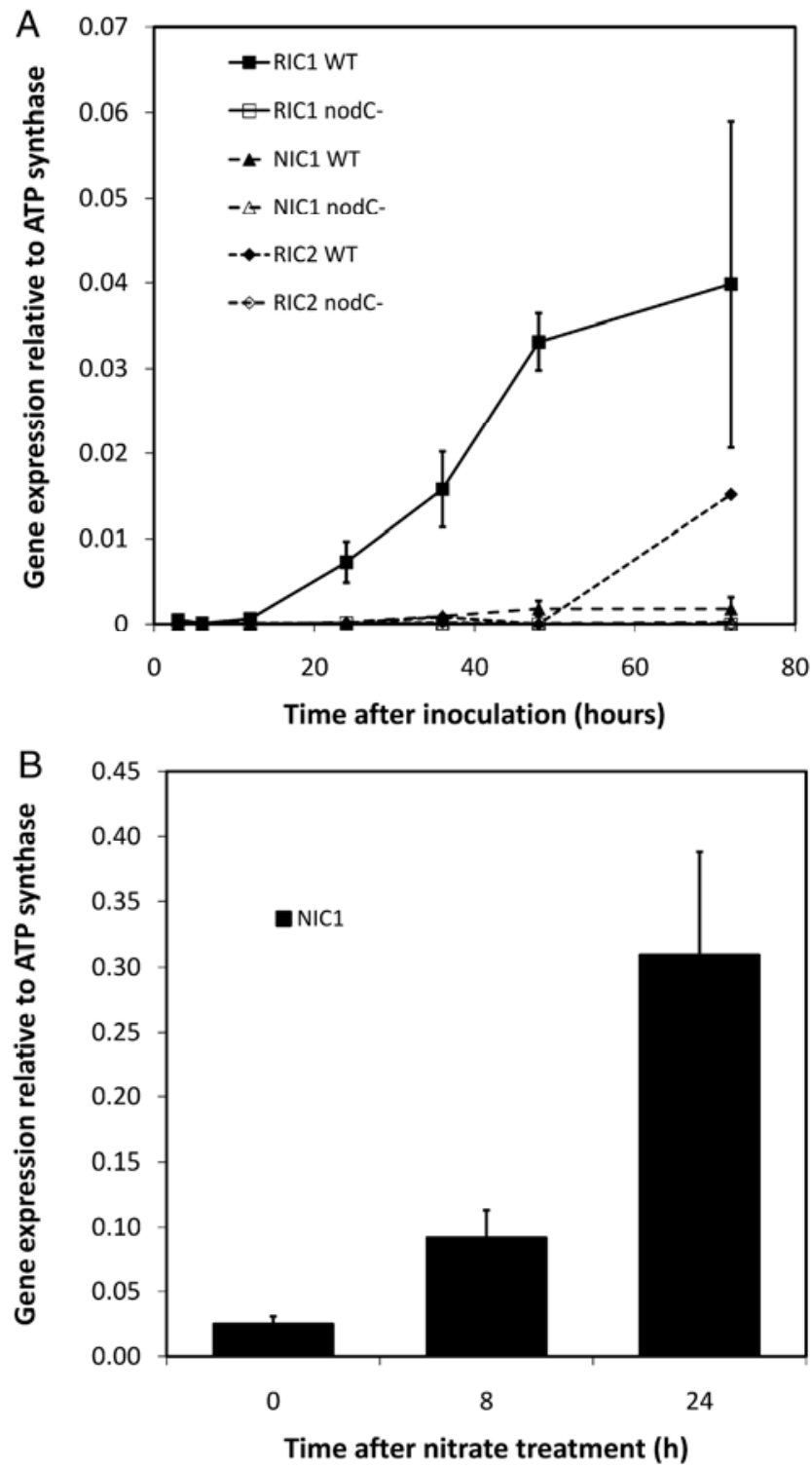

Fig. 4. Gene expression of soybean CLE genes in the zone of nodulation after rhizobia inoculation $\mathbf{A}$, Plants were inoculated with compatible (wild-type [WT]) or incompatible (nodC ${ }^{-}$) rhizobia before gene expression was quantified using reverse-transcription quantitative polymerase chain reaction. Error bars indicate mean \pm standard error (SE) of two biological replicates $(n=6)$. RICl was increased as early as $12 \mathrm{~h}$ after inoculation with WT bacteria whereas RIC2 was not induced until later time points. NICl was only slightly induced, though not significantly, and was not detectable until later. Gene expression of $\mathrm{NICl}$ in the root after nitrate treatment was significantly increased as early as $8 \mathrm{~h}$ after treatment with 10 $\mathrm{mM} \mathrm{KNO}_{3}$ and increased further at $24 \mathrm{~h} \mathrm{~B}$, Error bars indicate mean $\pm \mathrm{SE}$ $(n=4)$. 
constructs, the antisense construct portion was omitted and the intron left intact, because previous studies have shown that the inclusion of an intron can lead to higher and more consistent expression levels in transgenic plants (Norris et al. 1993).

Triparental mating was used to integrate the overexpression constructs into Agrobacterium rhizogenes K599, which efficiently induces the formation of transgenic hairy roots in soybean (Kereszt et al. 2007). An integrative vector was used because they have been shown to increase the transformation efficiency relative to that of binary vectors, which are commonly used in plant transformation (Hayashi et al. 2008). RT-qPCR analysis indicated that significant overexpression was achieved with each of these constructs (Supplementary Table S2). Overexpression of either RIC1 or RIC2 inhibited nodulation (RIC1: 0 nodules, RIC2: 0.6 nodules, and control: 9.45 nodules per root) in WT soybean plants. In contrast, there was no reduction in the number of nodules on equivalent nark (nod4, V370D) plants relative to vector-only transformed control nark plants (Fig. 6A). This indicates that nodule inhibition by CLE peptide overexpression is GmNARK dependent. Similarly, NICl overexpression significantly reduced nodulation $(P<0.05)$, although this reduction was not as strong as that observed for the $R I C$ genes. As was the case for $R I C 1$ and $R I C 2$, this reduction in nodulation was not observed in nod4 plants (Fig. 6B).

To determine whether this nodule inhibition was a systemic effect, the experiment was repeated with chimeric plants where both hairy roots and the primary root system were maintained. Nodulation was assessed on both transgenic roots and the WT primary root system. The two RIC genes inhibited nodulation on both the hairy roots and the primary roots in a systemic manner (Fig. 7). In contrast, NICl inhibited nodulation on the hairy roots while the primary roots were unaltered relative to nodulation on the vector-transformed control plants (Fig. 7).
Nitrate regulation of nodulation.

The strong systemic effect of AON has complicated the understanding of nitrate control of nodulation. Several studies have indicated that nitrate regulation is determined by the shoot (Day et al. 1989; Francisco and Akao, 1993), whereas others have highlighted the role of a local regulation in the root (Carroll and Gresshoff 1983; Carroll and Mathews 1990; Hinson 1975). In fact, both acting in parallel have recently been shown to be important for nodulation (Jeudy et al. 2010) and may regulate nodulation differently.

To determine what role NARK plays locally in nitrate regulation of nodulation, we investigated the nodule numbers of WT (Williams82) and supernodulation (nod4) (nts) plants that were grafted and treated with high or low levels of nitrate. Plants with an intact AON response (WT/nts and WT/WT) were used to assess whether NARK functions in the root as part of a local nitrate-controlled regulation of nodulation.

When treated with 5 or $10 \mathrm{mM} \mathrm{KNO}_{3}$, nodule numbers were reduced significantly ( $P=0.02$ and 0.002 , respectively) in grafted plants having a WT rootstock compared with those having a nod4 mutant rootstock (Fig. 8). There was no significant difference in nodule numbers when no nitrate was applied $(P=0.23)$. In concordance with previous studies (Delves et al. 1986, 1987), there was no difference observed in nodule numbers between the AON-defective grafting combinations ( $n t s / \mathrm{WT}$ and $n t s / n t s$ ) at any nitrate concentration (data not shown).

\section{Defining a putative CLE peptide-binding site in the GmNARK LRR domain.}

Using the Phyre protein structure prediction server (Kelley and Sternberg 2009), a model of the GmNARK LRR domain was determined for visualization using PyMOL (DeLano 2002). This model suggested a boomerang-shaped structure (Fig. 9A).

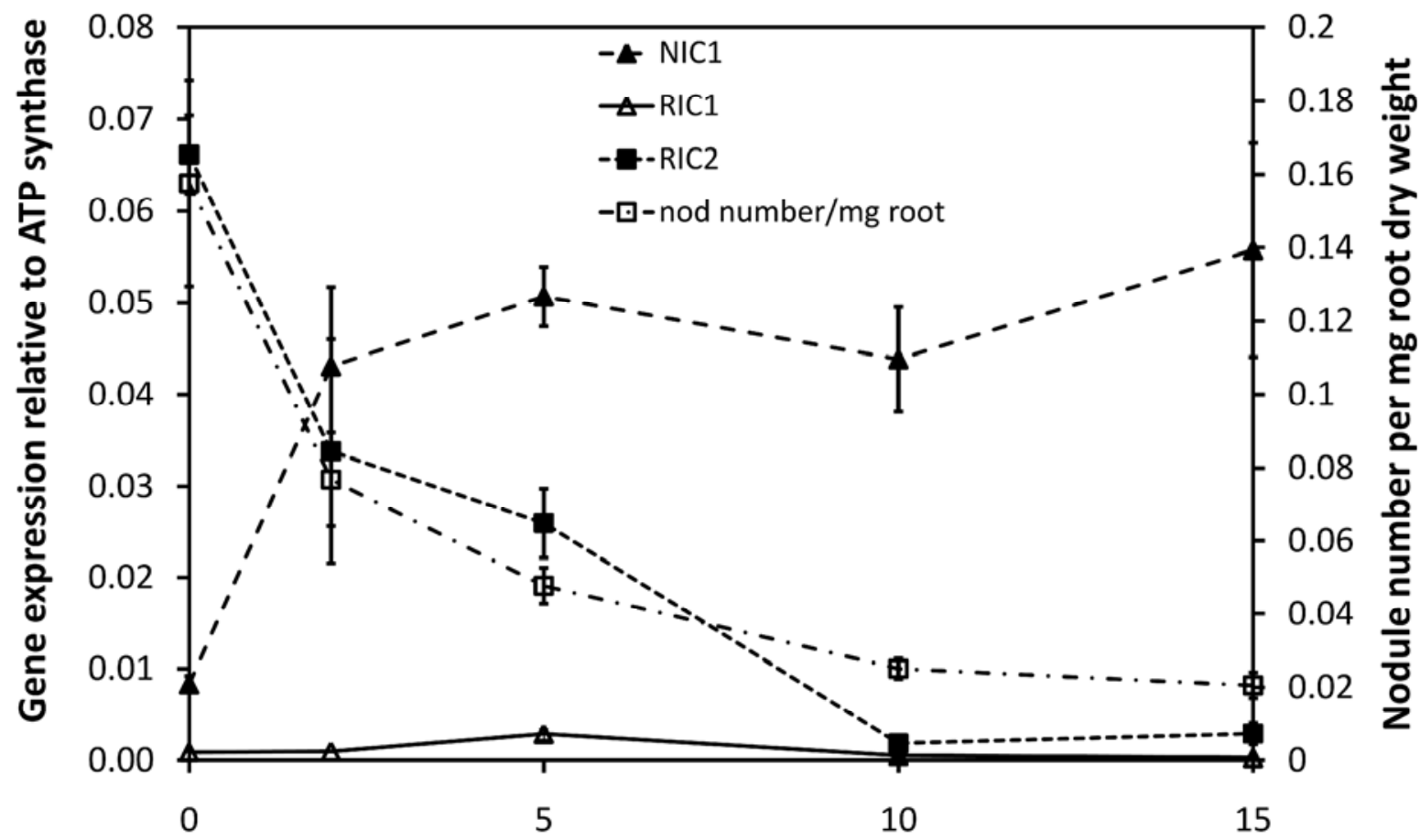

Nitrate concentration ( $\mathrm{mM}$ )

Fig. 5. CLE expression relative to nitrate concentration and nodule numbers. Tissue samples were harvested 2 weeks following inoculation and 3 weeks following nitrate treatment. Error bars indicate mean \pm standard error $(n=3)$. NIC1 expression was significantly induced by 2 mM nitrate and plateaued at 5 mM. RIC2 correlated strongly with nodule numbers, which were significantly reduced as nitrate concentration increased. RIC1 did not appear to correlate with nodulation at this later stage of development. 
Two missense mutants showing strong supernodulation phenotypes reminiscent of nonsense mutants in the GmNARK gene were positioned adjacent to a pronounced cleft in the central region of the LRR region (Fig. 9A). Despite being 24 amino acids apart (L346F and V370D) (J. Batley, unpublished data), both amino acids were adjacent in the predicted structure and directly flank the cleft. Though the detailed structure of the GmCLE peptides remains unknown, they may fit within the modeled cleft region. Absence of suppression of nodulation in nod4 plants transformed to overexpress the CLE genes further suggests that this region defines the putative CLE peptidebinding site.

\section{DISCUSSION}

Based on homology to CLE peptides that are necessary for nodule regulation in other legumes, we identified three inoculation- or nitrate-responsive CLE peptides in soybean. These three CLE peptides regulate soybean nodulation in a NARKand NF- or nitrate-dependent manner, although there are differences in their expression response and in the localization of their action (Table 1). The soybean CLE peptides share a high level of conservation in the CLE domain and have well-conserved motifs within the signal peptide and at the Cterminal.

Gene expression analyses showed that RIC1 and RIC2 are induced in response to Nod factor produced by compatible $B$. japonicum inoculation; however, differences in the timing of their induced expression suggest that they are not wholly redundant. RIC1 is expressed early, possibly in response to the initial signaling and cell division events induced following Bradyrhizobium sp. inoculation. This expression pattern is consistent with that of $L j C L E-R S 1 / 2$ and MtCLE13, which are reported to respond quickly to inoculation (Mortier et al. 2010; Okamoto et al. 2009). In the case of MtCLE13, expression was also observed in the ERN1mutant bit1-1 (Mortier et al. 2010), which is defective in the later stages of Nod factor signaling (Andriankaja et al. 2007; Middleton et al. 2007). In contrast, RIC2 expression correlates with the emergence of more mature nodule structures, similar to the expression of MtCLE12 (Mortier et al. 2010). Therefore, it may be induced following the onset of the nodule meristem or in response to nitrogen fixation. That multiple signals may act in parallel to regulate nodule numbers is not surprising in light of the findings by $\mathrm{Li}$
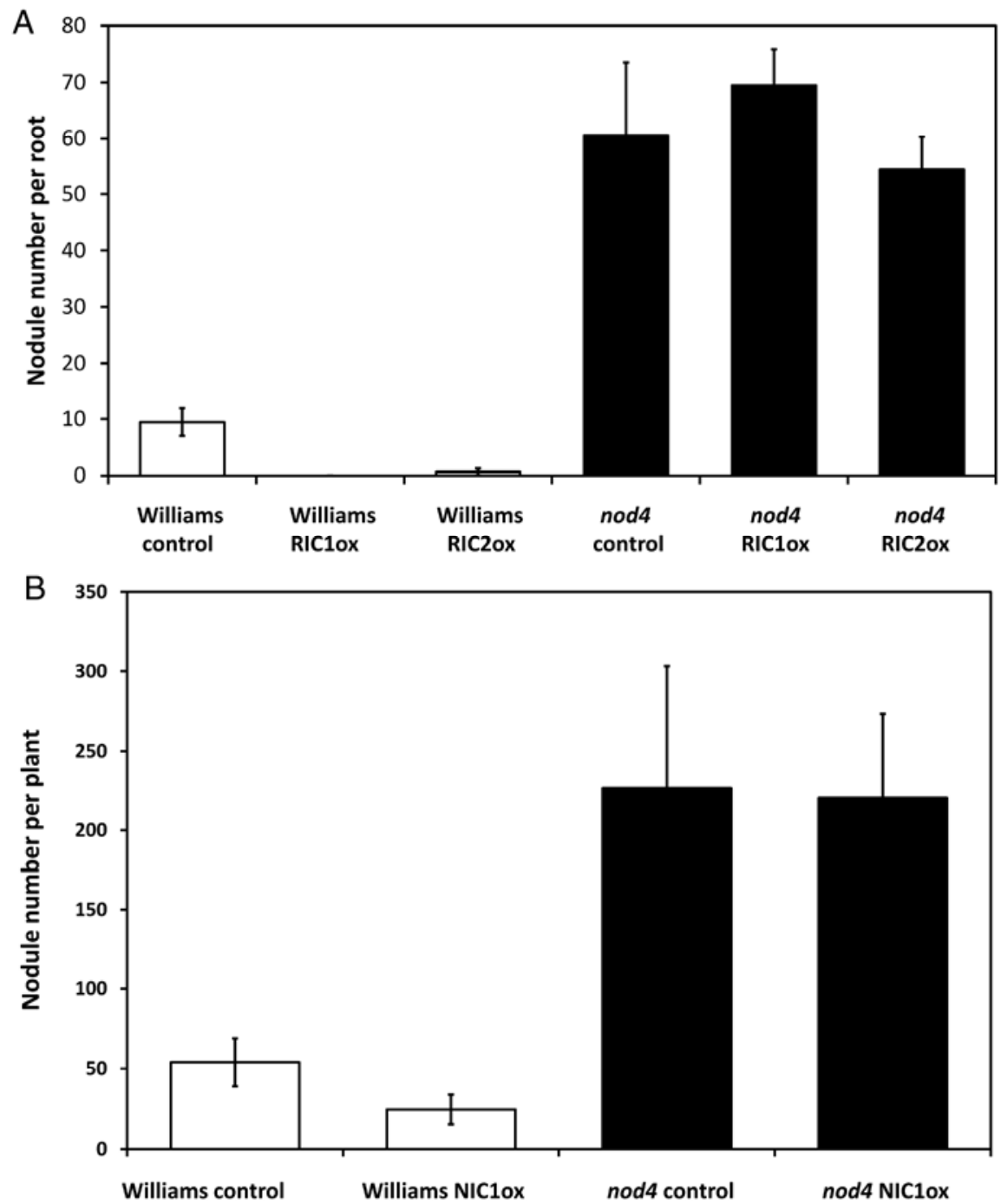

Fig. 6. Overexpression of inoculation induced CLE genes A, Hairy roots induced with the vector-only control showed a normal nodulation phenotype on Williams wild-type (WT) plants whereas nodules were significantly inhibited $(P<0.05)$ in WT roots overexpressing RIC1 or RIC2. In contrast, nodule numbers were not reduced in nod4 plants. Error bars indicate mean \pm standard error (SE) $(n=15)$. B, Overexpression of nitrate-induced CLE gene. Hairy roots induced with the vector-only control showed a normal nodulation phenotype on Williams WT plants whereas nodules were significantly reduced $(P<0.05)$ in WT roots overexpressing NICl. Nodule numbers were not reduced in the nod4 plants overexpressing NICl relative to controls. Error bars indicate mean \pm SE $(n=8)$. 
and associates (2009) that AON in pea may be activated at several developmental stages of nodulation.

Overexpression of both RIC1 and RIC2 was sufficient to elicit a systemic AON response and, in both cases, greatly reduced nodulation in WT plants. The complete lack of nodule inhibition in GmNARK mutant plants suggests that these CLE peptides are functioning in AON through NARK, possibly as the $\mathrm{Q}$ signal described in various AON models (Ferguson et al. 2010; Magori and Kawaguchi, 2009). Future experiments aimed at directly detecting the transport and function of these

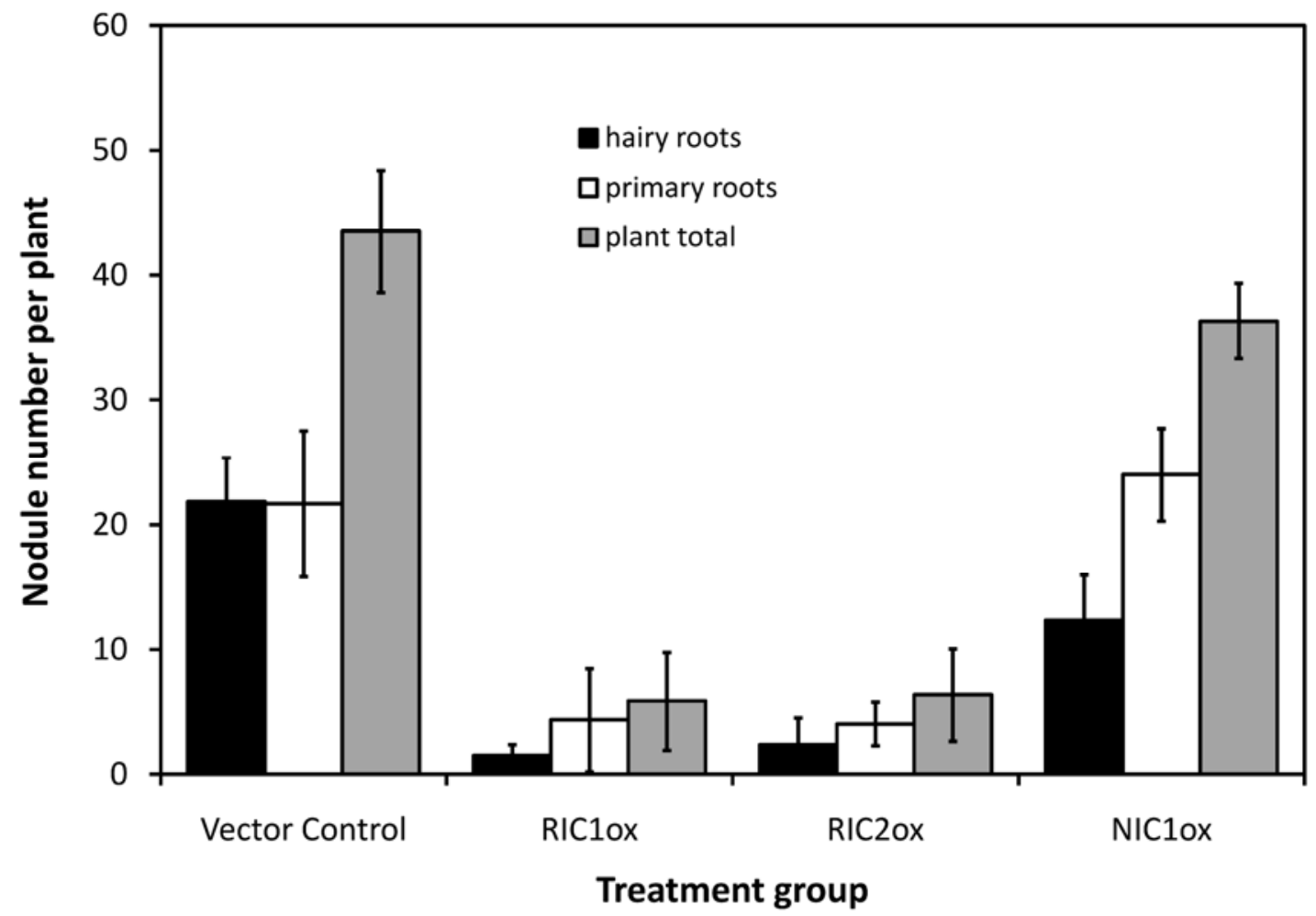

Fig. 7. Nodule numbers of plants having both untransformed primary roots and hairy roots overexpressing inoculation- or nitrate-induced CLE genes. Vectortransformed control plants showed no difference in nodulation between the hairy roots and the primary roots. Overexpressing RIC1 or RIC2 reduced nodulation on both the hairy roots and the primary roots, indicating a systemic inhibitory effect. In contrast, while nodule numbers were significantly reduced $(P<0.05)$ on hairy roots overexpressing $N I C 1$, no reduction was observed on the primary roots, indicating that NICl functions locally. Error bars indicate mean \pm standard error $(n=6)$.

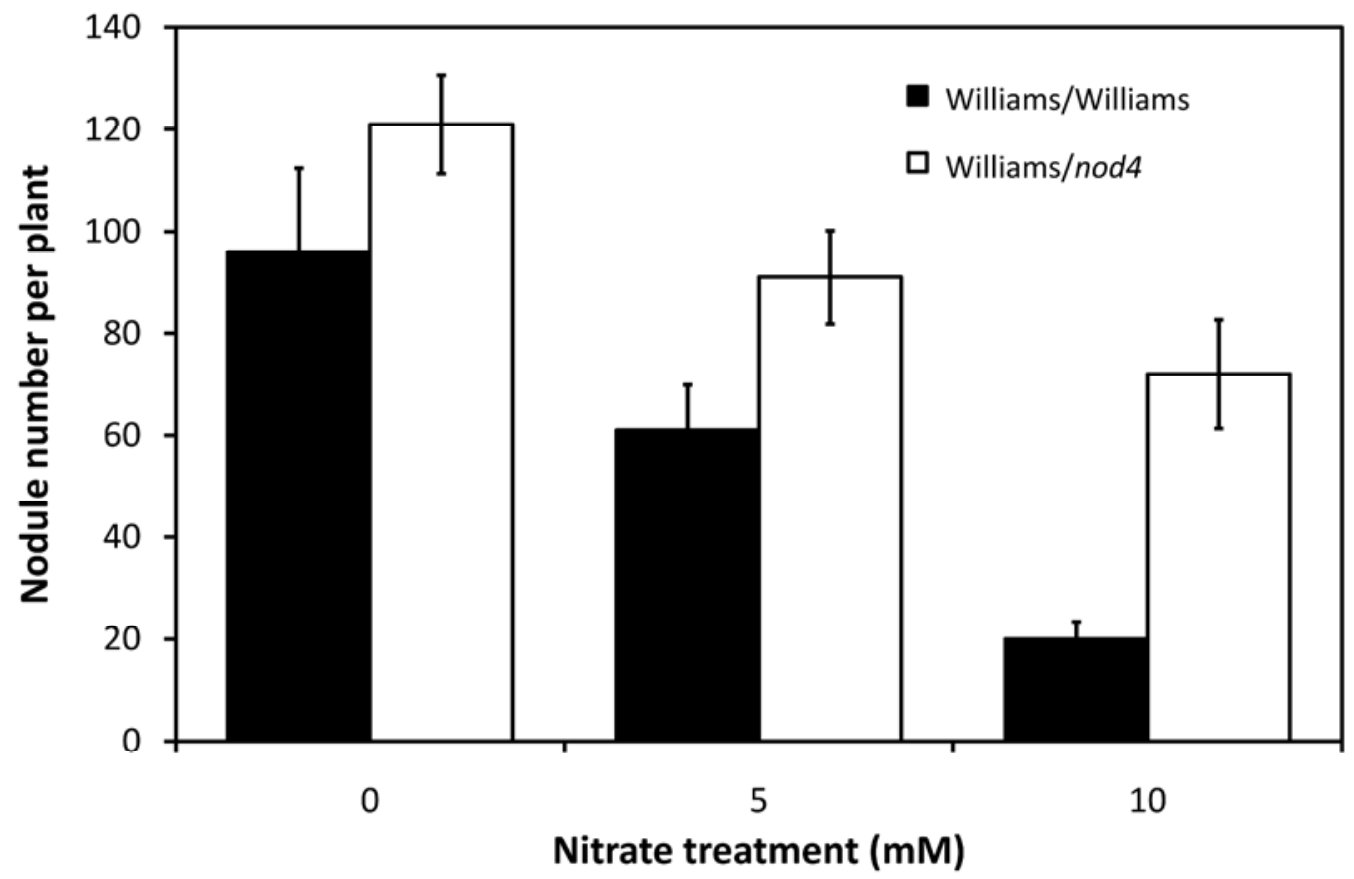

Fig. 8. Grafting of Williams (wild-type [WT]) scions with nod4 rootstocks under different nitrate conditions. Grafted plants having WT rootstock had significantly fewer nodules when treated with either 5 or $10 \mathrm{mM}$ nitrate compared with those having nod 4 rootstocks or those not treated with nitrate. Error bars indicate mean \pm standard error $(n=5)$. 
CLE peptides will help to verify these models. That the legume CLE genes have different expression patterns and timing appears to indicate that NARK and its orthologs in other legumes have evolved as a common receptor in various noduleregulation mechanisms. This would explain the dual role of NARK in AON and nitrate regulation of nodulation (Carroll et al. 1985a and b; Ferguson et al. 2010; Kouchi et al. 2010). That none of the CLE genes were regulated by AMF infection, despite this symbiosis also being regulated through NARK (Meixner et al. 2005, 2007), may indicate that other CLE peptides are involved in mycorrhizal control.

It appears that subtle differences exist between the CLE peptides identified in each of the three legume species in the manner in which inoculation- and nitrate-induced CLE peptides function. $L j C L E-R S 2$ is reported to be responsive to both nitrate treatment and rhizobia inoculation and to exhibit a systemic regulation response when overexpressed in L. japonicus hairy roots (Okamoto et al. 2009). This led to the proposal that $L j C L E-R S 2$ could systemically induce nodule regulation in response to both inoculation and nitrate in L. japonicus. In contrast, $\mathrm{NICl}$ was induced in response to nitrate but was not substantially altered by Bradyrhizobium spp. Moreover, it appears to function locally in the root and not systemically. Significant NICl expression was detected at the lowest nitrate levels we tested $\left(2 \mathrm{mM} \mathrm{KNO}_{3}\right)$ and reached a plateau at $5 \mathrm{mM}$ $\mathrm{KNO}_{3}$. Although there was a small increase in NICl expression $48 \mathrm{~h}$ after Bradyrhizobium sp. inoculation, the increase was minimal compared with that detected following nitrate treatment. It was also dramatically lower than that detected for RICl following Bradyrhizobium sp. inoculation. The NICl ex-
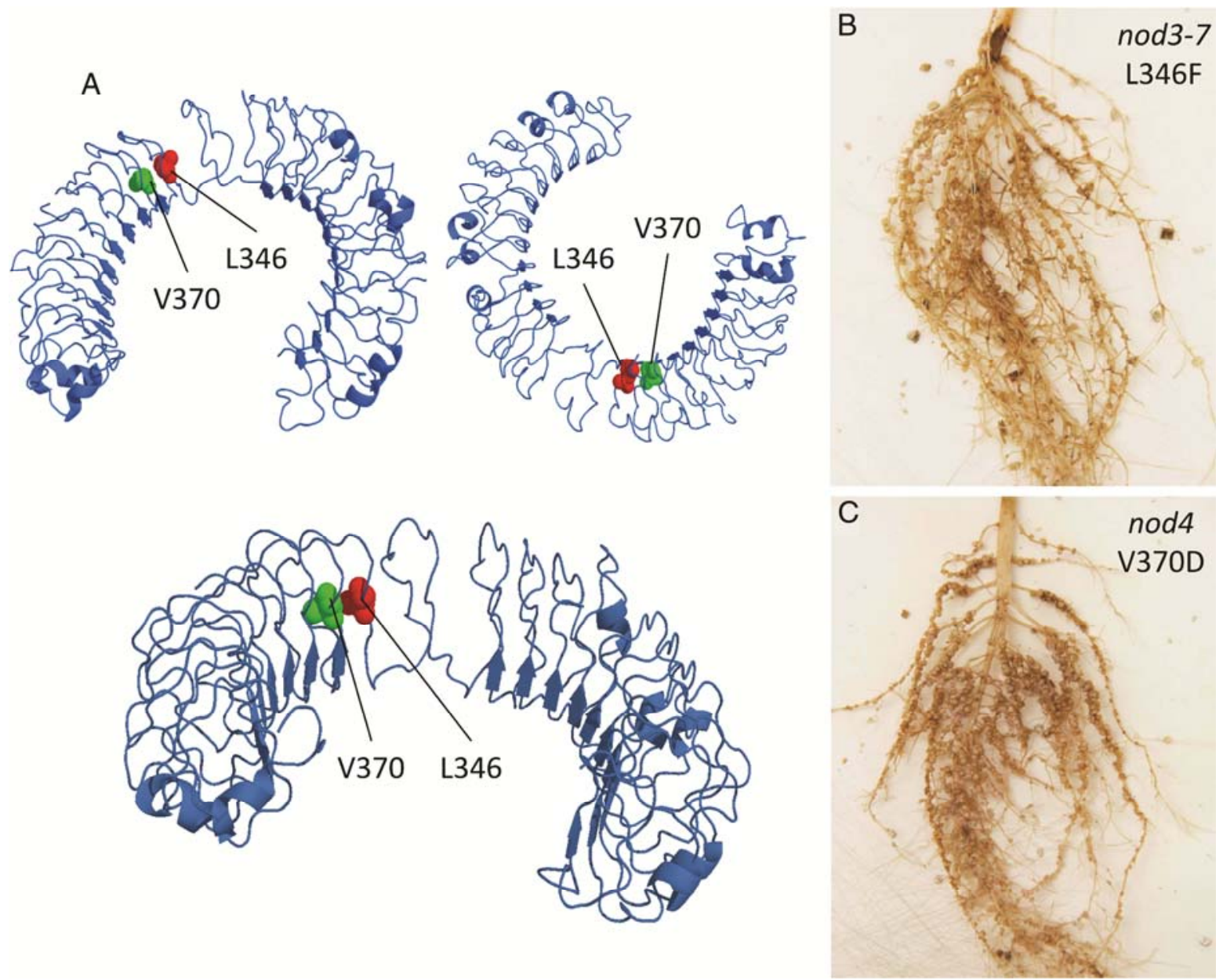

Fig. 9. Phyre modeling (Kelley and Strenberg 2009) (based on PDB: 1ZIW) of the NARK leucine-rich repeat domain revealed a boomerang-like structure with a distinct central cleft. A, Site of two amino acid residues (L346 and V370) that, when mutated, cause a supernodulation phenotype are shown flanking the central cleft and define the likely ligand binding site. B and C, Resulting supernodulation phenotypes caused by the L346 and V370 mutations of the nod3-7 and nod4 mutants, respectively.

Table 1. Comparison of legume CLEs capable of nodule regulation ${ }^{\mathrm{a}}$

\begin{tabular}{|c|c|c|c|c|c|c|c|}
\hline \multirow[b]{2}{*}{ Characteristic } & \multicolumn{3}{|c|}{ Glycine $\max$} & \multicolumn{2}{|c|}{ Medicago truncatula } & \multicolumn{2}{|c|}{ Lotus japonicus } \\
\hline & RIC1 & NIC1 & RIC2 & CLE12 & CLE13 & CLE RS1 & CLE RS2 \\
\hline Nitrate induced & No & Yes & No & NA & NA & Inhibited & Yes \\
\hline Early inoculation & Yes & No & No & No & Yes & Yes & Yes \\
\hline Late inoculation & No & No & Yes & Yes & Yes & NA & NA \\
\hline NARK/SUNN/HAR1 dependent inhibition & Yes & Yes & Yes & Allele specific & Allele specific & Yes & Yes \\
\hline Systemic activity & Yes & No & Yes & Yes & Yes & Yes & Yes \\
\hline CLE domain $3^{\prime}$ extension & Yes & No & Yes & No & Yes & Yes & Yes \\
\hline Signal peptide consensus sequence & Yes & Partial & Yes & Yes & Yes & Yes & Yes \\
\hline
\end{tabular}

${ }^{\mathrm{a}} \mathrm{NA}=$ not analyzed. 
pression pattern following inoculation may result from the evolutionary divergence of the CLE sequences and some conservation in their regulatory sequences. However, the reduced expression levels observed relative to RICl indicate it is not likely to be involved in inoculation-dependent nodule regulation. Overexpression of NICl caused an approximate $50 \%$ reduction in nodulation, indicating that it is capable of nodule inhibition, although not to the same degree as the inoculationinduced CLE genes. Consistent with the Bradyrhizobium sp.induced CLE peptides, NIC1 inhibition of nodulation was NARK dependent.

We reexamined the data from Delves and associates (1986) that investigated the grafting of AON-deficient plants in nitrate conditions and found that there may have been a nitrateinduced effect of the root-genotype on nodulation that was masked by the lack of AON in the shoot. The grafting experiments that we carried out confirmed this and showed that NARK acting in the root may regulate nodulation locally in addition to the systemic regulation of nodulation. Taken together with the NICl overexpression results, these grafting experiments highlight the local role for NARK in nitrate regulation of nodulation and indicate that NIC1 is likely a local inducer of NARK-dependent nodule regulation independent of the systemic AON mechanism. The reduced nodule inhibition response of NIC1 may be due to this local role in nodule inhibition and a reflection of successful transformation events or to differences in the signal peptide or CLE domain that may reduce the effectiveness of processing or activity of NIC1.

Increasingly, it appears that motifs outside of the CLE domain are required for the in planta function and specificity of CLE peptides. CLE activity is likely related to tissue specificity of the promoters, tissue localization caused by signal peptide trafficking, and post-translational modifications of the final peptide. The receptor specificity is likely due to the distinct structure of each CLE peptide (Meng et al. 2010), where most CLE peptides appear to share at least basic structural similarities due to a bend imparted by central glycine and proline residues (Cock and McCormick 2001). The putative Q CLE peptides have distinct double central glycine residues flanked by proline, which may impart AON receptor specificity. In Arabidopsis, CLE function is dependent on motifs outside of the CLE domain, particularly in the signal peptide (Meng et al. 2010). This is consistent with findings regarding the activity of CLE peptides produced by soybean cyst nematodes (Wang et al. 2010). Our work in soybean indicates that the signal peptide may be critical in differentiating the tissue specificity of the nitrate-responsive CLE from the inoculationresponsive CLE peptides. Aligning the sequences of the Bradyrhizobium sp.-induced CLE peptides to the previously reported inoculation-dependent CLE sequences allowed us to extend the conserved motif (FSTFFMTLQARSL) within the signal peptide that was first identified by Okamoto and associates (2009) and has not previously been reported outside of legumes. We found that this motif was common among the legume CLE peptides studied whereas, in GmNIC1, it was only partly conserved. Interestingly, the inoculation-dependent soybean CLE peptides and MtCLE13 also possessed the conserved proline residues close to the C-termini observed in LjCLE-RS1/2 (Okamoto et al. 2009) though the potential function of these residues remains unclear.

Previous studies have shown that nitrate treatment of one side of a split root system does not systemically change the nodule mass on the other side of the split root system (Tanaka et al. 1985). However, in the same experiment, nitrogen fixation was systemically reduced. This regulation may be due to asparagine transport in the phloem (Sulieman et al. 2010) and may explain the partial sensitivity of $n t s$ rootstock to nitrate in these experiments. We have extended this understanding of a local role of nitrate regulation in legume nodulation by demonstrating a local requirement for NARK in nodulation regulation that is dependent on NIC1. This appears to account for why NARK is expressed in the root (Nontachaiyapoom et al. 2007), despite it previously being believed to only be effective in the shoot. Our grafting experiments also demonstrate that nitrate regulation of nodulation acts locally through NARK in the root, because the presence of NARK in the shoot alone is not sufficient to regulate nodulation following nitrate treatment. The absence of several residues in the NIC1 signal peptide that are conserved in the inoculation-dependent CLE peptides may be responsible for its lack of systemic response. This may vary between legume species because it has been reported that the nitrate-responsive CLE peptide, LjCLE-RS2, can inhibit nodulation systemically in $L$. japonicus. Future domain swap experiments will be required to clarify the role of the signal peptide and other important domains within these CLE genes.

We propose an enhanced AON model in soybean that supports the recently reported model by Ferguson and associates (2010) where there is both a systemic and local role for NARK involving multiple CLE peptide ligands (Fig. 1). Future experiments will focus on detecting the peptides in planta to identify both their active and transport forms, in addition to studies aimed at better understanding the role of NARK and NIC1 in the nitrate-dependent regulation of nodulation.

\section{MATERIALS AND METHODS}

\section{General plant and bacterial growth conditions.}

Soybean (Glycine max) lines used include the WT Williams 82 and its isogenic supernodulating nark mutant lines, nod4 and nod3-7, and the WT Bragg and its isogenic hypernodulating nark mutant line, nts1116. Plants were grown in controlled glasshouse conditions $\left(28\right.$ and $26^{\circ} \mathrm{C}$, day and night, respectively, with a 16-h day) in autoclaved pots and vermiculite where sterile growing conditions were required. Seed requiring sterilization were treated with $70 \%$ ethanol and $3 \%$ $\mathrm{H}_{2} \mathrm{O}_{2}$ for $1 \mathrm{~min}$, followed by several rinses with water. Plants were watered as required with a modified nutrient solution lacking nitrogen (Herridge 1982). Plants were inoculated at an optical density at $600 \mathrm{~nm}$ of approximately 0.01 with B. japonicum $\mathrm{CB} 1809$ or the corresponding $\mathrm{NF}$ mutant nod $C^{-}$grown in yeast-mannitol broth at $28^{\circ} \mathrm{C}$ for 2 days. For nitrate treatments, plants were watered with the indicated solutions of $\mathrm{KNO}_{3}$ every 2 days. For grafting experiments, reciprocal grafting was carried out 8 days after sowing and the graft unions were allowed to recover for 6 days before $B$. japonicum inoculation. Nodulation was scored 3 weeks after inoculation. A Student's $t$ test was used to determine the statistical significance of nodulation differences.

\section{Bioinformatic analysis.}

Candidate inoculation- or nitrate-dependent CLE genes were identified by BLASTp searches of the Medicago expression atlas (Benedito et al. 2008) and soybean resources at NCBI and available through the Soybean Genome Project (Schmutz et al. 2010). The conserved C-terminal CLE motif of LjCLE-RS1/2 was used as the initial query sequence. Further searches were undertaken using the initial candidates to identify additional gene candidates and their genomic environment. Where partial sequences were obtained, the complete CDS was predicted from gene models available via phytozome or as determined by gene prediction programs (Burge and Karlin 1997; Salamov and Solovyev 2000). Multiple sequence alignments (Clustal X2) (Larkin et al. 2007) and signal peptide predictions (SignalP 3.0) (Bendtsen et al. 2004) were carried out 
using the soybean peptide sequences. Cluster analysis was obtained for each of the CLE genes from phytozome (Soybean Genome Project). Molecular modeling of the NARK LRR domain was carried out using residues 1 to 601 of the NARK protein (GenBank: AAN74865.1) at the Phyre web server (Kelley and Sternberg 2009) before visualization in PyMOL (DeLano 2002). The best-ranked hit for Phyre threading was to the humal toll-like receptor 3 ectodomain (PDB id: 1ziw).

\section{Molecular biology.}

The full-length CDS of RICl (Glyma13g36830), NICl (Glyma12g33660), and RIC2 (Glyma06g43680) was directionally cloned into the pKANNIBAL vector for expression of RNAi constructs (Wesley et al. 2001). Pfu polymerase (Stratagene, La Jolla, CA, U.S.A.) was used to amplify PCR products incorporating restriction nuclease sites from cDNA samples shown to express the target gene. XhoI/EcoRI (forward) and $K p n I$ (reverse) restriction sites were included in the primer sequences depending on internal restriction sites of each gene (full primer sequences are included in Supplementary Table S1). Likely clones were confirmed by direct DNA sequencing and capillary separation. Constructs were subcloned into p15SRK2 or pM1KCK1 integration vectors (A. Kereszt, unpublished) as a Not 1 fragment before triparental mating to introduce the constructs into A. rhizogenes K599. A. rhizogenes was subsequently used for the induction of transgenic soybean hairy roots according to Kereszt and associates (2007), with slight modification for the chimeric plants, where the primary root system was not removed.

\section{RT-qPCR analysis.}

For gene-expression analyses, tissue was snap frozen and homogenized in liquid nitrogen using a mortar and pestle. RNA was extracted using TRIzol reagent according to the manufacturer's instructions (Invitrogen, San Diego, CA, U.S.A.). DNAse treatment (Fermentas, Burlington, Canada) was performed on $1 \mu \mathrm{g}$ of RNA in the presence of $\mathrm{MgCL}_{2}$. cDNA was synthesized with SuperScript III (Invitrogen) from $0.5 \mu \mathrm{g}$ of DNAsetreated RNA. RT-qPCR was conducted using an ABI 7900HT cycler in 384-well plates with SYBR green fluorescence detection. All reactions were performed in duplicate for at least three biological replicates using intron-spanning primers where possible and a target amplicon of approximately $100 \mathrm{bp}$. Gene expression values were calculated relative to ATP synthase or GmCons6 (Libault et al. 2008) after normalization for PCR efficiency and plot correlation $\left(R^{2}\right)$ values of each primer pair as determined by LinRegPCR 7.5 (Ramakers et al. 2003). A Student's $t$ test was used to determine the statistical signifycance of differences in the relative expression levels.

\section{ACKNOWLEDGMENTS}

This work was supported by the Australian Research Council through a Centre of Excellence grant. Additional support was provided to D. E. Ried by an Australian Government DIISR Australian Postgraduate Award. We thank D. Li for her excellent technical assistance, S. Hayashi for providing the early inoculation time-course cDNA, S. Schaarschmidt and B. Hause for providing the cDNA from mycorrhizae infected plants, G. Stacey for providing the nod $C^{-}$rhizobia, and $\mathrm{J}$. Batley for providing the NARK sequence of the nod 4 and nod3-7 plants.

\section{LITERATURE CITED}

Andriankaja, A., Boisson-Dernier, A., Frances, L., Sauviac, L., Jauneau, A., Barker, D., and de Carvalho-Niebel, F. 2007. AP2-ERF transcription factors mediate Nod factor dependent Mt ENOD11 activation in root hairs via a novel cis-regulatory motif. Plant Cell 19:2866-2885.

Bendtsen, J. D., Nielsen, H., von Heijne, G., and Brunak, S. 2004. Improved prediction of signal peptides: SignalP 3.0. J. Mol. Biol. 340:783-795.
Benedito, V. A., Torres-Jerez, I., Murray, J. D. Andriankaja, A., Allen, S. Kakar, K., Wandrey, M., Verdier, J., Zuber, H., Ott, T., Moreau, S., Niebel, A., Frickey, T., Weiller, G., He, J., Dai, X., Zhao, P. X., Tang, Y., and Udvardi M. K. 2008. A gene expression atlas of the model legume Medicago truncatula. Plant J. 55:504-513.

Bhuvaneswari, T. V., Turgeon, B. G., and Bauer, W. D. 1980. Early events in the infection of soybean (Glycine max L. Merr.) by Rhizobium japonicum. Plant Physiol. 66:1027-1031.

Bhuvaneswari, T. V., Bhagwat, A. A., and Bauer, W. D. 1981. Transient susceptibility of root cells in four common legumes to nodulation by Rhizobia. Plant Physiol. 68:1144-1149.

Burge, C., and Karlin, S. 1997. Prediction of complete gene structures in human genomic DNA. J. Mol. Biol. 268:78-94.

Caetano-Anollés, G., and Gresshoff, P. M. 1990. Early induction of feedback regulatory responses governing nodulation in soybean. Plant Sci. 71:69-81.

Caetano-Anollés, G., and Gresshoff, P. M. 1991a. Alfalfa controls nodulation during the onset of Rhizobium-induced cortical cell division. Plant Physiol. 95:366-373.

Caetano-Anolles, G., and Gresshoff, P. 1991b. Plant genetic control of nodulation. Annu. Rev. Microbiol. 45:345-382.

Calvert, H., Pence, M., Pierce, M., Malik, N., and Bauer, W. 1984. Anatomical analysis of the development and distribution of Rhizobium infections in soybean roots. Can. J. Bot. 62:2375-2384.

Carroll, B., and Gresshoff, P. 1983. Nitrate inhibition of nodulation and nitrogen fixation in white clover. Z. Pflanzenphysiol. 110:69-76.

Carroll, B. J., and Mathews, A. 1990. Nitrate inhibition of nodulation in legumes. In Molecular Biology of Symbiotic Nitrogen Fixation., pp. 159-180. Edited by P. M. Gresshoff. CRC Press, Inc. Boca Raton, FL, U.S.A.

Carroll, B. J., McNeil, D. L., and Gresshoff, P. M. 1985a. Isolation and properties of soybean [Glycine $\max (\mathrm{L}$.) Merr.] mutants that nodulate in the presence of high nitrate concentrations. Proc. Natl. Acad. Sci. U.S.A. 82:4162-4166.

Carroll, B. J., McNeil, D. L., and Gresshoff, P. M. 1985b. A supernodulation and nitrate-tolerant symbiotic (nts) soybean mutant. Plant Physiol. 78:34-40.

Clark, S. E., Williams, R. W., and Meyerowitz, E. M. 1997. The CLAVATA1 gene encodes a putative receptor kinase that controls shoot and floral meristem size in Arabidopsis. Cell 89:575-585.

Cock, J., and McCormick, S. 2001. A large family of genes that share homology with CLAVATA3. Plant Physiol. 126:939-942.

Crooks, G., Hon, G., Chandonia, J., and Brenner, S. 2004. WebLogo: A sequence logo generator. Genome Res. 14:1188-1190.

Day, D. A., Carroll, B. J., Delves, A. C., and Gresshoff, P. M. 1989 Relationship between autoregulation and nitrate inhibition of nodulation in soybeans. Physiol. Plant. 75:37-42.

Debellé, F., Rosenberg, C., and Dénarié, J. 1992. The Rhizobium, Bradyrhizobium, and Azorhizobium NodC proteins are homologous to yeast chitin synthases. Mol. Plant-Microbe Interact. 5::443-446.

DeLano, W. 2002. the PYMOL Molecular Graphics System. DeLano Scientific, San Carlos, CA, U.S.A.

Delves, A. C., Mathews, A., Day, D. A., Carter, A. S., Carroll, B. J., and Gresshoff, P. M. 1986. Regulation of the soybean-Rhizobium nodule symbiosis by shoot and root factors. Plant Physiol. 82:588-590.

Delves, A. C., Higgins, A. V., and Gresshoff, P. M. 1987. Shoot control of supernodulation in a number of mutant soybeans, Glycine $\max$ (L.) Merr. Aust. J. Plant Physiol. 14:689-694.

Diévart, A., and Clark, S. 2004. LRR-containing receptors regulating plant development and defense. Development 131:251-261.

Ferguson, B., and Gresshoff, P. M. 2009. Soybean as a model legume. Grain Legumes 53:7.

Ferguson, B. J., and Mathesius, U. 2003. Signaling interactions during nodule development. J. Plant Growth Regul. 22:47-72.

Ferguson, B. J., Indrasumunar, A., Hayashi, S., Lin, M.-H., Lin, Y.-H., Reid, D. E., and Gresshoff, P. M. 2010. Molecular analysis of legume nodule development and autoregulation. J. Integr. Plant Biol. 52:61-76.

Fiers, M., Hause, G., Boutilier, K., Casamitjana-Martinez, E., Weijers, D., Offringa, R., van der Geest, L., van Lookeren Campagne, M., and Liu, C.-M. 2004. Mis-expression of the CLV3/ESR-like gene CLE19 in Arabidopsis leads to a consumption of root meristem. Gene 327:37-49.

Fletcher, J. C., Brand, U., Running, M. P., Simon, R., and Meyerowitz, E. M. 1999. Signaling of cell fate decisions by CLAVATA3 in Arabidopsis shoot meristems. Science 283:1911-1914.

Francisco, P., and Akao, S. 1993. Autoregulation and nitrate inhibition of nodule formation in soybean cv. Enrei and its nodulation mutants. J. Exp. Bot. 44:547-553.

Frugoli, J. 2010. RDN, a conserved protein of unknown function in $M$. truncatula regulates nodule number through root signaling. Fifth Inter- 
national Congress on Legume Genetics and Genomics. Asilomar, CA, U.S.A.

Gonzalez-Rizzo, S., Crespi, M., and Frugier, F. 2006. The Medicago truncatula CRE1 cytokinin receptor regulates lateral root development and early symbiotic interaction with Sinorhizobium meliloti. Plant Cell 18:2680-2693.

Gresshoff, P. M., and Delves, A. C. 1986. Plant genetic approaches to symbiotic nodulation and nitrogen fixation in legumes. Plant Gene Res. 3:159-206.

Hayashi, S., Gresshoff, P. M., and Kinkema, M. 2008. Molecular analysis of lipoxygenases associated with nodule development in soybean. Mol. Plant-Microbe Interact. 21:843-853.

Heckmann, A., Lombardo, F., Miwa, H., Perry, J., Bunnewell, S., Parniske, M., Wang, T., and Downie, J. 2006. Lotus japonicus nodulation requires two GRAS domain regulators, one of which is functionally conserved in a non-legume. Plant Physiol. 142:1739-1750.

Herridge, D. F. 1982. Relative abundance of ureides and nitrate in plant tissues of soybean as a quantitative assay of nitrogen fixation. Plant Physiol. 70:1-6.

Hinson, K. 1975. Nodulation responses from nitrogen applied to soybean half-root systems. Agron. J. 67:799-804.

Hirakawa, Y., Kondo, Y., and Fukuda, H. 2010. Regulation of vascular development by CLE peptide-receptor systems. J. Integr. Plant Biol. 52:8-16

Indrasumunar, A., Kereszt, A., Searle, I., Miyagi, M., Li, D., Nguyen, C., Men, A., Carroll, B., and Gresshoff, P. 2010a. Inactivation of duplicated Nod-Factor Receptor 5 (NFR5) genes in recessive loss-of-function nonnodulation mutants of allotetraploid soybean (Glycine max L. Merr.) Plant Cell Physiol. 51:201-214.

Indrasumunar, A., Searle, I., Lin, M.-H., Kereszt, A., Men, A., Carroll, B. J., and Gresshoff, P. M. 2010b. Nodulation factor receptor kinase $1 \alpha$ controls nodule organ number in soybean (Glycine max L. Merr.). Plant J. doi: 10.1111/j.1365-313X.2010.04398.x.

Ishikawa, K., Yokota, K., Li, Y. Y., Wang, Y., Liu, C.-T., Suzuki, S., Aono, T., and Oyaizu, H. 2008. Isolation of a novel root-determined hypernodulation mutant rdh1 of Lotus japonicus. Soil Sci. Plant Nutr. 54:259-263.

Ito, Y., Nakanomyo, I., Motose, H., Iwamoto, K., Sawa, S., Dohmae, N., and Fukuda, H. 2006. Dodeca-CLE peptides as suppressors of plant stem cell differentiation. Science 313:842-845.

Jeudy, C., Ruffel, S., Freixes, S., Tillard, P., Santoni, A. L., Morel, S., Journet, E.-P., Duc, G., Gojon, A., Lepetit, M., and Salon, C. 2010 Adaptation of Medicago truncatula to nitrogen limitation is modulated via local and systemic nodule developmental responses. New Phytol. 185:817-828.

Jiang, Q., and Gresshoff, P. 2002. Shoot control of hypernodulation and aberrant root formation in the har1-1 mutant of Lotus japonicus. Funct. Plant Biol. 29:1371-1376.

Kelley, L. A., and Sternberg, M. J. E. 2009. Protein structure prediction on the Web: A case study using the Phyre server. Nat. Protocols 4:363-371.

Kereszt, A., Li, D., Indrasumunar, A., Nguyen, C. D. T., Nontachaiyapoom, S., Kinkema, M., and Gresshoff, P. M. 2007. Agrobacterium rhizogenesmediated transformation of soybean to study root biology. Nat. Protocols 2:948-952.

Kondo, T., Sawa, S., Kinoshita, A., Mizuno, S., Kakimoto, T., Fukuda, H., and Sakagami, Y. 2006. A plant peptide encoded by CLV3 identified by in situ MALDI-TOF MS analysis. Science 313:845-848.

Kondo, T., Nakamura, T., Yokomine, K., and Sakagami, Y. 2008. Dual assay for MCLV3 activity reveals structure-activity relationship of CLE peptides. Biochem. Biophys. Res. Commun. 377:312-316.

Kosuta, S., Hazledine, S., Sun, J., Miwa, H., Morris, R. J., Downie, J. A., and Oldroyd, G. E. D. 2008. Differential and chaotic calcium signatures in the symbiosis signaling pathway of legumes. Proc. Natl. Acad. Sci. U.S.A. 105:9823-9828.

Kouchi, H., Imaizumi-Anraku, H., Hayashi, M., Hakoyama, T., Nakagawa, T., Umehara, Y., Suganuma, N., and Kawaguchi, M. 2010. How many peas in a pod? Legume genes responsible for mutualistic symbioses underground. Plant Cell Physiol. 51:1381-1397.

Krusell, L., Madsen, L. H., Sato, S., Aubert, G. G., Genua, A., Szczyglowski, K., Duc, G. R., Kaneko, T., Tabata, S., Bruijnk, F. D., Pajuelo, E., Sandal, N., and Stougaard, J. 2002. Shoot control of root development and nodulation is mediated by a receptor-like kinase. Nature 420:422-426.

Krusell, L., Sato, N., Fukuhara, I., Koch, B. E. V., Grossmann, C., Okamoto, S., Oka-Kira, E., Otsubo, Y., Aubert, G., Nakagawa, T., Sato, S., Tabata, S., Duc, G., Parniske, M., Wang, T. L., Kawaguchi, M., and Stougaard, J. 2011. The Clavata2 genes of pea and Lotus japonicus affect autoregulation of nodulation. Plant J. ePublished ahead of print. doi: 10.1111/j.1365-313X.2010.04474.x.

Larkin, M. A., Blackshields, G., Brown, N. P., Chenna, R., McGettigan, P.
A., McWilliam, H., Valentin, F., Wallace, I. M., Wilm, A., and Lopez, R. 2007. Clustal W and Clustal X version 2.0. Bioinformatics 23:29472948.

Li, D., Kinkema, M., and Gresshoff, P. M. 2009. Autoregulation of nodulation (AON) in Pisum sativum (pea) involves signalling events associated with both nodule primordia development and nitrogen fixation. J. Plant Physiol. 166:955-967.

Libault, M., Thibivilliers, S., Bilgin, D., Radwan, O., Benitez, M., Clough, S., and Stacey, G. 2008. Identification of four soybean reference genes for gene expression normalization. Plant Genome 1:44-54

Lin, Y.-H., Ferguson, B. J., Kereszt, A., and Gresshoff, P. M. 2010. Suppression of hypernodulation in soybean by a leaf-extracted, NARKand Nod factor-dependent low molecular mass fraction. New Phytol. 185:1074-1086.

Magori, S., and Kawaguchi, M. 2009. Long-distance control of nodulation: Molecules and models. Mol. Cells 27:129-134.

Magori, S., Oka-Kira, E., Shibata, S., Umehara, Y., Kouchi, H., Hase, Y., Tanaka, A., Sato, S., Tabata, S., and Kawaguchi, M. 2009. TOO MUCH LOVE, a root regulator associated with the long-distance control of nodulation in Lotus japonicus. Mol. Plant-Microbe Interact. 22:259-268.

Mathews, A., Carroll, B. J., and Gresshoff, P. M. 1989. Development of Bradyrhizobium infections in supernodulating and non-nodulating mutants of soybean (Glycine max [L.] Merrill). Protoplasma 150:40-47.

Meixner, C., Ludwig-Müller, J., Miersch, O., Gresshoff, P., Staehelin, C., and Vierheilig, H. 2005. Lack of mycorrhizal autoregulation and phytohormonal changes in the supernodulating soybean mutant nts1007. Planta 222:709-715.

Meixner, C., Vegvari, G., Ludwig-Muller, J., Gagnon, H., Steinkellner, S. Staehelin, C., Gresshoff, P., and Vierheilig, H. 2007. Two defined alleles of the LRR receptor kinase GmNARK in supernodulating soybean govern differing autoregulation of mycorrhization. Physiol. Plant. 130:261-270.

Meng, L., Ruth, K. C., Fletcher, J. C., and Feldman, L. 2010. The roles of different CLE domains in Arabidopsis CLE polypeptide activity and functional specificity. Mol. Plant 232:1061-1074.

Middleton, P. H., Jakab, J., Penmetsa, R. V. Starker, C. G., Doll, J., Kalo, P., Prabhu, R., Marsh, J. F., Mitra, R. M., Kereszt, A., Dudas, B., VandenBosch, K., Sharon, R. L., Cook, D. R., Kiss, G. B. and Oldroyd, G. E. D. 2007. An ERF transcription factor in Medicago truncatula that is essential for Nod factor signal transduction. Plant Cell 19:1221-1234.

Mortier, V., Den Herder, G., Whitford, R., Van de Velde, W., Rombauts, S., D'haeseleer, K., Holsters, M., and Goormachtig, S. 2010. CLE peptides control Medicago truncatula nodulation locally and systemically. Plant Physiol. 153:222-237.

Murray, J. D., Karas, B. J., Sato, S., Tabata, S., Amyot, L., and Szczyglowski, K. 2007. A cytokinin perception mutant colonized by Rhizobium in the absence of nodule organogenesis. Science 315:101-104.

Ni, J., and Clark, S. E. 2006. Evidence for functional conservation, sufficiency, and proteolytic processing of the CLAVATA3 CLE domain. Plant Physiol. 140:726-733.

Ni, J., Guo, Y., Jin, H., Hartsell, J., and Clark, S. 2010. Characterization of a CLE processing activity. Plant Mol. Biol. 75:67-75.

Nishimura, R., Hayashi, M., Wu, G. J., Kouchi, H., Imaizumi-Anraku, H., Murakami, Y., Kawasaki, S., Akao, S., Ohmori, M., and Nagasawa, M. 2002a. HAR1 mediates systemic regulation of symbiotic organ development. Nature 420:426-429.

Nishimura, R., Ohmori, M., Fujita, H., and Kawaguchi, M. 2002b. A Lotus basic leucine zipper protein with a RING-finger motif negatively regulates the developmental program of nodulation. Proc. Natl. Acad. Sci. U.S.A. 99:15206-15210.

Nontachaiyapoom, S., Scott, P. T., Men, A. E., Kinkema, M., Schenk, P. M., and Gresshoff, P. M. 2007. Promoters of orthologous Glycine max and Lotus japonicus nodulation autoregulation genes interchangeably drive phloem-specific expression in transgenic plants. Mol. PlantMicrobe Interact. 20:769-780.

Norris, S., Meyer, S., and Callis, J. 1993. The intron of Arabidopsis thaliana polyubiquitin genes is conserved in location and is a quantitative determinant of chimeric gene expression. Plant Mol. Biol. 21:895-906.

Oelkers, K., Goffard, N., Weiller, G. F., Gresshoff, P. M., Mathesius, U. and Frickey, T. 2008. Bioinformatic analysis of the CLE signaling peptide family. BMC Plant Biol. 8:1.

Ogawa, M., Shinohara, H., Sakagami, Y., and Matsubayashi, Y. 2008. Arabidopsis CLV3 peptide directly binds CLV1 ectodomain. Science 319:294.

Ohyama, K., Shinohara, H., Ogawa-Ohnishi, M., and Matsubayashi, Y. 2009. A glycopeptide regulating stem cell fate in Arabidopsis thaliana. Nat. Chem. Biol. 5:578-580.

Oka-Kira, E., Tateno, K., Miura, K.-I., Haga, T., Hayashi, M., Harada, K. Sato, S., Tabata, S., Shikazono, N., Tanaka, A., Watanabe, Y., Fukuhara, I., Nagata, T., and Kawaguchi, M. 2005. klavier (klv), A novel hyper- 
nodulation mutant of Lotus japonicus affected in vascular tissue organization and floral induction. Plant J. 44:505-515.

Okamoto, S., Ohnishi, E., Sato, S., Takahashi, H., Nakazono, M., Tabata S., and Kawaguchi, M. 2009. Nod factor, nitrate-induced CLE genes that drive systemic regulation of nodulation. Plant Cell Physiol. 50:6777 .

Oldroyd, G. E., and Downie, J. A. 2008. Coordinating nodule morphogenesis with rhizobial infection in legumes. Annu. Rev. Plant Biol. 59:519-546

Oldroyd, G. E. D., and Downie, J. A. 2006. Nuclear calcium changes at the core of symbiosis signalling. Curr. Opin. Plant Biol. 9:351-357.

Olsson, J., Nakao, P., Bohlool, B., and Gresshoff, P. 1989. Lack of systemic suppression of nodulation in split root systems of supernodulating soybean (Glycine max [L.] Merr.) mutants. Plant Physiol. 90:1347-1352.

Penmetsa, R. V., Frugoli, J. A., Smith, L. S., Long, S. R., and Cook, D. R. 2003. Dual genetic pathways controlling nodule number in Medicago truncatula. Plant Physiol. 131:998-1008.

Postma, J., Jacobsen, E., and Feenstra, W. 1988. Three pea mutants with an altered nodulation studied by genetic analysis and grafting. J. Plant Physiol. 132:424-430.

Ramakers, C., Ruijter, J. M., Deprez, R. H. L., and Moorman, A. F. M. 2003. Assumption-free analysis of quantitative real-time polymerase chain reaction (PCR) data. Neurosci. Lett. 339:62-66.

Sagan, M., and Duc, G. 1996. Sym28 and Sym29, two new genes involved in regulation of nodulation in pea (Pisum sativum L.). Symbiosis 20:229-245.

Sagan, M., and Gresshoff, P. 1996. Developmental mapping of nodulation events in pea (Pisum sativum L.) using supernodulating plant genotypes and bacterial variability reveals both plant and Rhizobium control of nodulation regulation. Plant Sci. 117:167-179.

Salamov, A., and Solovyev, V. 2000. Ab initio gene finding in Drosophila genomic DNA. Genome Res. 10:516-522.

Sanjuan, J., Carlson, R. W., Spaink, H. P., Bhat, U. R., Barbour, W. M., Glushka, J., and Stacey, G. 1992. A 2-O-methylfucose moiety is present in the lipo-oligosaccharide nodulation signal of Bradyrhizobium japonicum. Proc. Natl. Acad. Sci. U.S.A. 89:8789-8793.

Schauser, L., Roussis, A., Stiller, J., and Stougaard, J. 1999. A plant regulator controlling development of symbiotic root nodules. Nature 402:191194

Schmutz, J., Cannon, S. B., Schlueter, J. Ma, J., Hyten, D. L., Song, Q., Mitros, T., Nelson, W., May, G. D., Gill, N., Peto, M. F., Shu, S., Goodstein, D., Thelen, J. J., Cheng, J., Sakurai, T., Umezawa, T., Shinozaki, K., Du, J., Bhattacharyya, M., Sandhu, D., Grant, D. M., Joshi, T., Libault, M., Zhang, X., Hguyen, H., Valliyodan, B., Xu, D., Futrell-Griggs, M., Abernathy, B., Hellsten, U., Berry, K., Grimwood, J., Yu, Y., Wing, R. A., Cregan, P. B., Stacey, G., Specht, J., Rokhsar, D., Shoemaker, R. C., and Jackson, S. 2010. Genome sequence of the paleopolyploid soybean (Glycine $\max$ (L.) Merr.). Nature 463:178 183.

Schnabel, E., Journet, E.-P., Carvalho-Niebel, F. d., Duc, G., and Frugoli, J. 2005. The Medicago truncatula SUNN gene encodes a CLV1-like leucine-rich repeat receptor kinase that regulates nodule number and root length. Plant Mol. Biol. 58:809-822.

Searle, I. R., Men, A. E., Laniya, T. S., Buzas, D. M., Iturbe-Ormaetxe, I., Carroll, B. J., and Gresshoff, P. M. 2003. Long-distance signaling in nodulation directed by a CLAVATA1-like receptor kinase. Science 299:109-112.

Shinohara, H., and Matsubayashi, Y. 2010. Arabinosylated glycopeptide hormones: New insights into CLAVATA3 structure. Curr. Opin. Plant Biol. 13:515-519.

Sulieman, S., Fischinger, S., Gresshoff, P., and Schulze, J. 2010. Asparagine as a major factor in the $\mathrm{N}$-feedback regulation of $\mathrm{N}_{2}$ fixation in Medicago truncatula. Physiol. Plant. 140:21-31.

Tanaka, A., Fujita, K., and Terasawa, H. 1985. Growth and dinitrogen fixation of soybean root system affected by partial exposure to nitrate. Soil Sci. Plant Nutr. 31:637-645.

Tirichine, L., Sandal, N., Madsen, L. H., Radutoiu, S., Albrektsen, A. S., Sato, S., Asamizu, E., Tabata, S., and Stougaard, J. 2007. A gain-offunction mutation in a cytokinin receptor triggers spontaneous root nodule organogenesis. Science 315:104-107.

Udvardi, M. K., Price, G. D., Gresshoff, P. M., and Day, D. A. 1988. A dicarboxylate transporter on the peribacteroid membrane of soybean nodules. FEBS (Fed. Eur. Biochem. Soc.) Lett. 231:36-40.

Vernie, T., Moreau, S., de Billy, F., Plet, J., Combier, J. P., Rogers, C., Oldroyd, G., Frugier, F., Niebel, A., and Gamas, P. 2008. EFD is an ERF transcription factor involved in the control of nodule number and differentiation in Medicago truncatula. Plant Cell 20:2696-2713.

Wang, J., Lee, C., Replogle, A., Joshi, S., Korkin, D., Hussey, R., Baum, T., Davis, E., Wang, X., and Mitchum, M. 2010. Dual roles for the variable domain in protein trafficking and host-specific recognition of Heterodera glycines CLE effector proteins. New Phytol. 216:293-300.

Wesley, S., Helliwell, C., Smith, N., Wang, M., Rouse, D., Liu, Q., Gooding, P., Singh, S., Abbott, D., Stoutjesdijk, P., Robinson, S., Gleave, A., Green, A., and Waterhouse, P. 2001. Construct design for efficient, effective and high-throughput gene silencing in plants. Plant J. 27:581-590.

Wopereis, J., Pajuelo, E., Dazzo, F., Jiang, Q., Gresshoff, P., de Bruijn, F., Stougaard, J., and Szczyglowski, K. 2000. Short root mutant of Lotus japonicus with a dramatically altered symbiotic phenotype. Plant J. 23:97-114

\section{AUTHOR-RECOMMENDED INTERNET RESOURCE}

Phytozome Glycine max (soybean) database: www.phytozome.net/soybean 